\title{
Research on the Protection Level Transformation and Upgrading Technology of the W-beam Barrier on Highway
}

\author{
Bao Deng ${ }^{1, a}$, Yong-gang Tai ${ }^{1, a}$, Hui-xue Liu ${ }^{1, a}$, Xiang-yang Pan ${ }^{2, a}$, \\ Shu-fang $\mathrm{Ge}^{1, \mathrm{a}}$ and Wen-xuan Cai ${ }^{1, \mathrm{a}}$ \\ ${ }^{1}$ Rioh transport consultants Ltd, Beijing China \\ ${ }^{2}$ Fujian province expressway co., LTD, Fuzhou China \\ a16460472@qq.com
}

Keywords: Highway; Old W-beam Barrier; Protection Level; Transformation; Upgrading

Abstract: After 20 years of rapid development of highway in China, the w-beam barrier is the most widely used form of barrier. Recycling and reusing of old barrier are often involved in daily maintenance and expansion project. This paper established the actual protection grade calculation model of the old W-beam barrier through investigation on old W-beam barrier. Considering previous research experience and theoretical calculation, five kinds of barrier structure are put forward which can enhance barrier protection ability. Two design schemes are selected through the computer simulation analysis comparisons and are tested through the full-scale impact test with real vehicle. Test results show that the protection level of selected two design schemes meet the level A protection requirements of the current assessment standard.

\section{Introduction}

In early years, the w-beam barrier of highway constructed in China is based on "Specification for Design and Construction of Expressway Safety Appurtenances (JTJ 074-94)", of which the protection energy is $93 \mathrm{~kJ}$. Withthe changes of traffic flow characteristics in freeway, the protection level of original barrier cannot meet the safety and security requirement. Therefore, using the existing structure of the old w-beam barrier and enhancing the protection level energy from the 93kJ to the current "Specification for Design of Highway Safety Facilities (JTG D81-2006)" requirements of $160 \mathrm{~kJ}$, can not only enhance safety, but also reflect the new conception of saving, low-carbon and environmental protection.

The protection of w-beam barrier is a system function. Old w-beam barrier protection system includes column system and w-beam plates system. The protection level of the w-beam barrier is related to the sum of absorbed deformation energy of columns and w-beam plates. The factors which affect the protection energy of column and w-beam plates include the following aspects [1], as shown in Figure 1. 


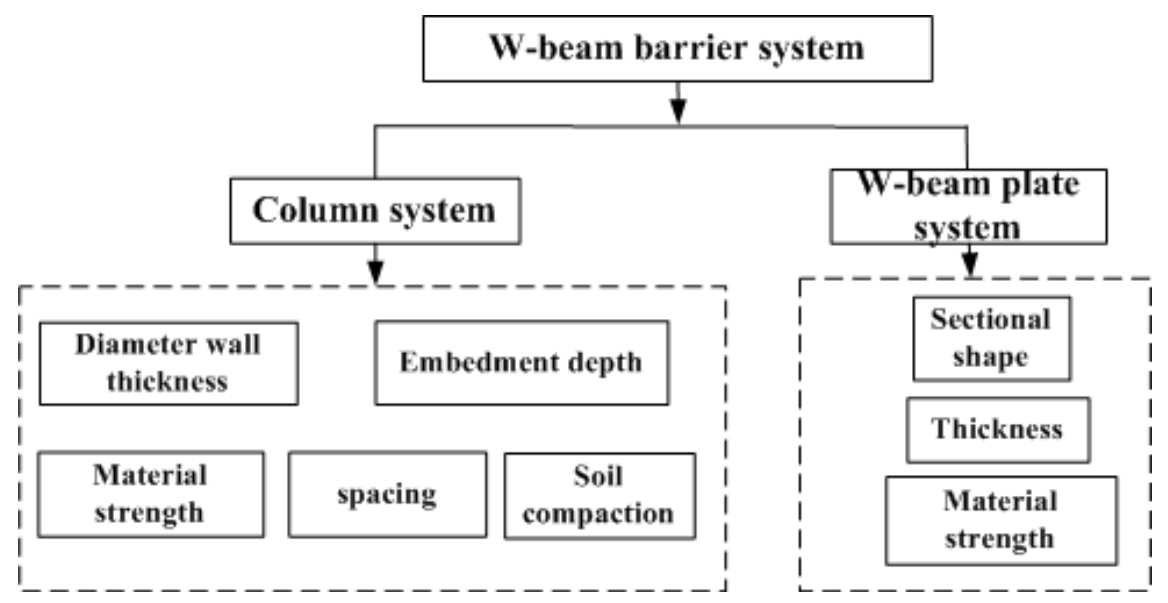

Fig.1 W-beam barrier protection level factors

\section{The calculation model of enhancing the protection level of old w-beam barrier}

\section{Model}

Here use the standard Gr-A-4E barriers reference to estimate the protection energy of the w-beam barrier. The deformation resistant of barrier systems is used to calculate the actual barrier protection energy. Based on this, basic assumptions are as follows:

(1) Vehicle impact energy of the across-road direction on the barriers mostly absorbed by the deformation of columns and beams;

(2) The deformation energy of columns and w-beam plates is equal to the protection level of barrier.

(3) Under the standard conditions of the vehicle impact, the length of barrier section which absorbs energy is within a certain range.

(4) The barrier column and the w-beam plates are steel-plastic material.

(5) The protection level of the barrier is mainly influenced by the performance of energy absorption of columns and w-beam plates [2] [3] [4].

Barrier calculation model of actual protection energy is shown in equation (1):

$$
E_{2}=k \times\left(\sum_{i=1}^{m} \mathrm{D}_{\mathrm{i}}+\sum_{j=1}^{n} \mathrm{D}_{\mathrm{j}}\right)=k \times\left(\sum_{i=1}^{m} k_{P} k_{h} k_{l} M_{p i}\left|\theta_{i}\right|+\sum_{j=1}^{n} M_{p j}\left|\theta_{j}\right|\right)
$$

In the equation

$E_{2}$ - Actual protection level of barrier $(\mathrm{kJ})$;

$k$ - Correction coefficient (considering barrier system energy consumption, corrosion, etc.), (0.8-1.0);

$\mathrm{D}_{\mathrm{i}}-$ Absorbed deformation energy of column $(\mathrm{kJ})$;

$i$ - Numbers of deformed column;

$\mathrm{D}_{\mathrm{j}}$ - Absorbed deformation energy of $\mathrm{W}$-beam plate $(\mathrm{kJ})$;

$j$ - Numbers of deformation W-beam plate;

$\mathrm{k}_{\mathrm{p}}$ - Coefficient of soil compaction;

$\mathrm{k}_{\mathrm{h}}$ - Coefficient of depth of column embedment;

$\mathrm{k}_{1}$ - Column spacing coefficient;

$M_{p i}$ - Ultimate plastic bending moment of column $(\mathrm{N} \cdot \mathrm{m})$; 
$\theta_{i}$ - Relative angle at the plastic deformation area of the NO.i column;(rad)

$M_{p j}$ - Ultimate plastic bending moment of $\mathrm{w}$-beam plate $(\mathrm{N} \cdot \mathrm{m})$;

$\theta_{j}$ - Relative angle at the plastic deformation area of the NO.i plates[5];

\section{Main Parameter Value}

1) Main range of energy absorbed section of w-beam barrier

According to the theoretical analysis, for grade A w-beam barrier under the impact conditions, the average length of total deformation section is $12.21 \mathrm{~m}$. Thus, Numbers of deformed columnis 4 , the Numbers of deformation $\mathrm{W}$-beam plate $\mathrm{j}$ is 3 . Figure 2 shows the main energy-absorbing area of w-beam barrier before and after deformation.

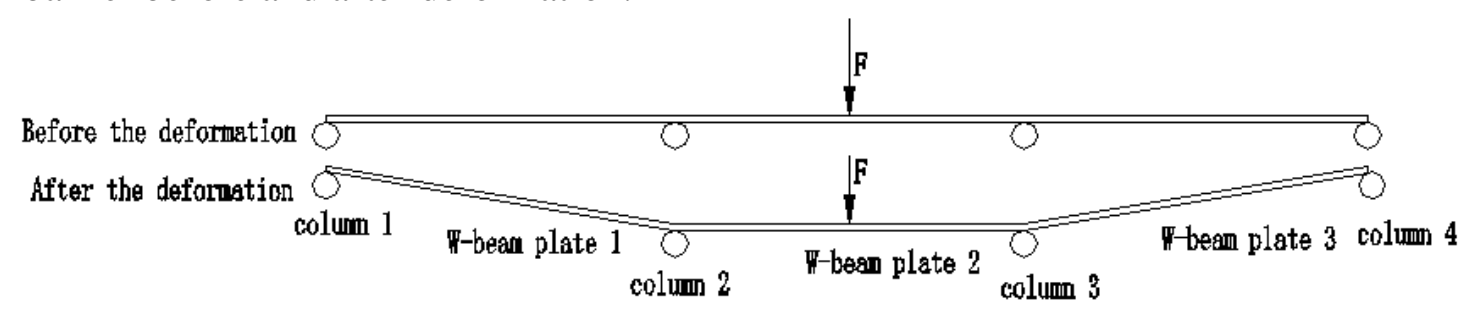

Fig.2 W-beam barrier energy deformation range diagram

2) Analys is of energy-absorbing of column

According to the research and barrier material performance test of expressway w-beam barrier, column is circular and typical sizes are mainly $\Phi 114 \mathrm{~mm} \times 4.5 \mathrm{~mm}$ and $\Phi 140 \mathrm{~mm} \times 4.5 \mathrm{~mm}$. Factors affecting energy absorbing of barrier column include the following aspects: the column section modulus, strength, column embedment depth, subgrade compaction, relative plastic deformation bending angle of the column.Figure 3 shows the schematic diagram soil foundation cracking and measurement parameter[6].
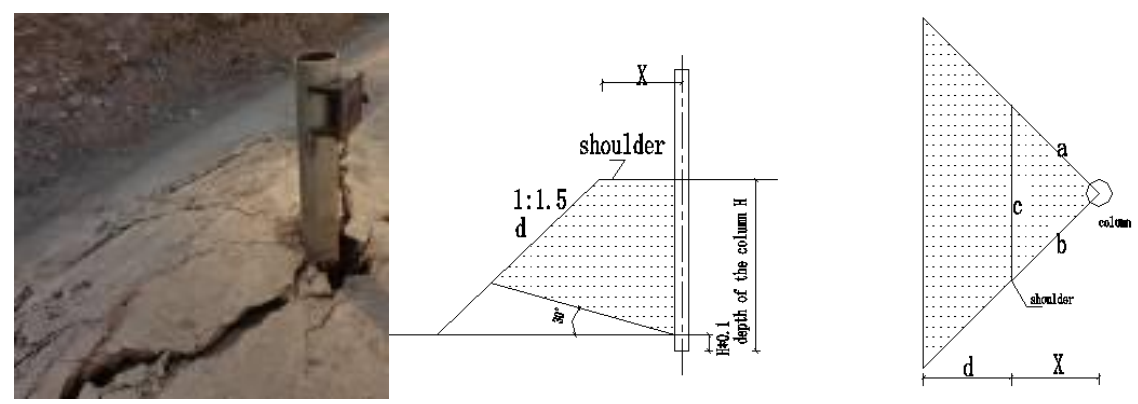

Fig.3Soil foundation cracking and measurement parameter schematic diagram

With the same degree of compaction of soil and distance between column and road shoulder, the ratio of the ultimate strength, of which between different embedded depth and the embedded depth which is less than $1.1 \mathrm{~m}$, is in a small range. When embedded depth is larger than $1.4 \mathrm{~m}$, the ratio is $1.45-1.48$, column $1.4 \mathrm{~m}$ depth, the ratio is $1.21-1.23$. This conclusion has high conformity with experimental coefficient of the column embedded depth test. Therefore, in the calculation of the maximum energy-absorbing column, column embedment depth coefficient uses the experimental values, but the coefficient of compaction uses the actual degree of soil compaction [7][8]. Table 1 shows the column energy dissipation with different conditions. 
Tab.1 Column energy dissipation calculation under different conditions

\begin{tabular}{|c|c|c|c|c|c|c|}
\hline $\begin{array}{c}\text { Column } \\
\text { Specifications }(\mathrm{mm})\end{array}$ & $\begin{array}{c}\text { Type / } \\
\text { Embedment } \\
\text { depth }(\mathrm{cm})\end{array}$ & $\begin{array}{c}\text { Embedment } \\
\text { depth } \\
\text { coefficients }\end{array}$ & $\begin{array}{l}\text { Column } \\
\text { spacing } \\
\text { (m) }\end{array}$ & $\begin{array}{c}\text { Column } \\
\text { spacing } \\
\text { coefficient }\end{array}$ & $\begin{array}{c}\text { Soil } \\
\text { compaction } \\
\text { coefficient }\end{array}$ & $\begin{array}{l}\text { Column energy } \\
\text { consumption }(\mathrm{kJ})\end{array}$ \\
\hline \multirow{8}{*}{$\Phi 114 * 4.5$} & Buried pile & 0.94 & \multirow{4}{*}{4} & 1 & 0.95 & 38.98 \\
\hline & 110 & 1 & & 1 & 0.95 & 41.47 \\
\hline & 125 & 1.36 & & 1 & 0.95 & 56.40 \\
\hline & 140 & 1.44 & & 1 & 0.95 & 59.71 \\
\hline & Buried pile & 0.94 & \multirow{4}{*}{2} & 1.5 & 0.95 & 58.47 \\
\hline & 110 & 1 & & 1.5 & 0.95 & 62.20 \\
\hline & 125 & 1.36 & & 1.5 & 0.95 & 84.59 \\
\hline & 140 & 1.44 & & 1.5 & 0.95 & 89.57 \\
\hline \multirow{8}{*}{$\Phi 140 * 4.5$} & Buried pile & 0.94 & \multirow{4}{*}{4} & 1 & 0.95 & 65.06 \\
\hline & 110 & 1 & & 1 & 0.95 & 69.22 \\
\hline & 125 & 1.36 & & 1 & 0.95 & 94.14 \\
\hline & 140 & 1.44 & & 1 & 0.95 & 99.67 \\
\hline & Buried pile & 0.94 & \multirow{4}{*}{2} & 1.5 & 0.95 & 97.60 \\
\hline & 110 & 1 & & 1.5 & 0.95 & 103.83 \\
\hline & 125 & 1.36 & & 1.5 & 0.95 & 141.20 \\
\hline & 140 & 1.44 & & 1.5 & 0.95 & 149.51 \\
\hline
\end{tabular}

\section{3) Analys is of energy absorbing of w-beam plate}

According to the highway investigation, there are two w-beam thicknesses: $3 \mathrm{~mm}$ and $4 \mathrm{~mm}$. the factors of w-beam energy consumption are the section modulus of w-beam, strength, relative bending angle of plate plastic deformation. Calculation of W-beam energy absorbing is shown in Table 2.

Tab.2 W-beam energy dissipation calculation

\begin{tabular}{c|c|c|c|c|c|c|c}
\hline $\begin{array}{c}\text { Thickness } \\
(\mathrm{mm})\end{array}$ & $\begin{array}{c}\text { Moment } \\
\text { of } \\
\text { inertia } \\
\left(\mathrm{cm}^{4}\right)\end{array}$ & $\begin{array}{c}\text { Radius of } \\
\text { gyration }(\mathrm{cm})\end{array}$ & $\begin{array}{c}\text { Section } \\
\text { modulus }\left(\mathrm{cm}^{3}\right)\end{array}$ & $\begin{array}{c}\text { Yield } \\
\text { Strength }(\mathrm{kN} / \mathrm{cm})\end{array}$ & $\begin{array}{c}\text { Amount } \\
\text { of } \\
\text { plates }\end{array}$ & $\begin{array}{c}\text { Relative } \\
\text { angle(rad) }\end{array}$ & $\begin{array}{c}\text { W-beam } \\
\text { maximum } \\
\text { consumption } \\
\text { energy }(\mathrm{kJ})\end{array}$ \\
\hline 3 & 106.6 & 4.25 & 25.08 & 37.71 & 3 & 0.5 & 28.38 \\
\hline 4 & 143.05 & 4.25 & 33.66 & 37.71 & 3 & 0.5 & 38.08 \\
\hline
\end{tabular}

\section{Old barrier reuse design and theoretical calculations}

According to the actual situation of the reuse of the old barrier panels, combined with the experiences of research, design and renovation project of barrier, five kinds of recycling modification program is put forward [9] [10], which is shown in Table 3. 
Tab.3 The retrofit scheme and protection grade calculation

\begin{tabular}{|c|c|c|c|}
\hline Serial number & $\begin{array}{c}\text { Description of original barrier } \\
\text { structure }\end{array}$ & Description of Renovation or new part & $\begin{array}{l}\text { Protection } \\
\text { class } \\
\text { calculated } \\
\quad(\mathrm{kJ}) \\
\end{array}$ \\
\hline $\begin{array}{l}\text { Option I: } \\
\text { Replace with } \\
4 \mathrm{~mm} \\
\text { three-wave } \\
\text { beam }\end{array}$ & $\begin{array}{c}\text { Column } \\
\text { Specifications: } \varnothing 140 \mathrm{~mm} \times 4.5 \mathrm{~mm} \\
\text { w-beam stickiness }: 3 \mathrm{~mm}\end{array}$ & $\begin{array}{c}\text { Column :Keep the original column spacing, } \\
\text { depth } \\
\text { w-beam plate: Replace with } 4 \mathrm{~mm} \\
\text { three-wave beam }\end{array}$ & 154.14 \\
\hline $\begin{array}{l}\text { Option } \Pi \text { : } \\
\text { extra column, } \\
\text { double w-beam } \\
\text { plate } \\
\end{array}$ & $\begin{array}{l}\text { Column } \\
\text { Specific ations: } \varnothing 114 \mathrm{~mm} \times 4.5 \\
\mathrm{~mm} \\
\text { w-beam stickiness:3mm }\end{array}$ & $\begin{array}{c}\text { Column :Add extra } \\
\varnothing 140 \mathrm{~mm} \times 4.5 \mathrm{mmc} \text { olumn } \\
\text { w-beam plate: Add extra } 3 \mathrm{~mm} \mathrm{w} \text {-beam } \\
\text { plate(old w-beam plate can be used) } \\
\end{array}$ & 157.94 \\
\hline $\begin{array}{l}\text { Option } \mathrm{II} \text { :extra } \\
\text { column, Add } \\
3 \mathrm{~mm} \text { single } \\
\text { wave beam }\end{array}$ & $\begin{array}{l}\text { Column } \\
\text { Specific ations: } \varnothing 114 \mathrm{~mm} \times 4.5 \\
\text { mm } \\
\text { w-beam stickiness:3mm }\end{array}$ & $\begin{array}{c}\text { Column : Add extra } \\
\varnothing 140 \mathrm{~mm} \times 4.5 \mathrm{mmc} \text { olumn, Heightening the } \\
\text { original column casing } \\
\text { w-beam plate: Add } 3 \mathrm{~mm} \text { single wave beam }\end{array}$ & 186.18 \\
\hline $\begin{array}{c}\text { Option } \\
\text { IV:8-shape } \\
\text { w-beam plate }\end{array}$ & $\begin{array}{c}\text { Column } \\
\text { Specifications }: \varnothing 140 \mathrm{~mm} \times 4.5 \mathrm{~mm} \\
\text { w-beam stickiness }:: 3 \mathrm{~mm}\end{array}$ & $\begin{array}{l}\text { Column: Add extra } \varnothing 140 \mathrm{~mm} \times 4.5 \mathrm{~mm} \\
\text { column } \\
\text { w-beam plate: Add extra } 3 \mathrm{~mm} \text { w-beam } \\
\text { plate(old w-beam plate can be used) }\end{array}$ & 197.9 \\
\hline $\begin{array}{l}\text { Option } V \text { :extra } \\
\text { column, } \\
\text { replace } 4 \mathrm{~mm} \\
\text { thick channel } \\
\text { steel }\end{array}$ & $\begin{array}{l}\text { Column } \\
\text { Specific ations: } \varnothing 114 \mathrm{~mm} \times 4.5 \\
\mathrm{~mm} \\
\text { w-beam stickiness: } 3 \mathrm{~mm}\end{array}$ & $\begin{array}{c}\text { Column: Add extra } \emptyset 140 \mathrm{~mm} \times 4.5 \mathrm{~mm} \\
\text { column } \\
\text { w-beam plate: replace } 4 \mathrm{~mm} \text { thick channel } \\
\text { steel }\end{array}$ & 164.69 \\
\hline
\end{tabular}

\section{Computer Simulation Analysis of modification programs}

\section{The simulation model and simulation parameters}

Based on the main features of small passenger cars, medium bus and medium trucks in China, the vehicle finite element model is established. For small car finite element model, there are totally 41,011 nodes elements, 42,185 shell elements, 340 body elements, 92 beam elements; The finite element model of medium-sized passenger car has totally 44,834 nodes elements, 43,564 shell elements, 16 beam elements, 24 the spring elements, and 784 other elements; the finite element model of medium truck has totally 52,681 nodes elements, 28,944 housing elements, 16,416 body elements, 66 beam elements,32 spring elements and 1930 other elements. Figure 4 are the model demonstrations.
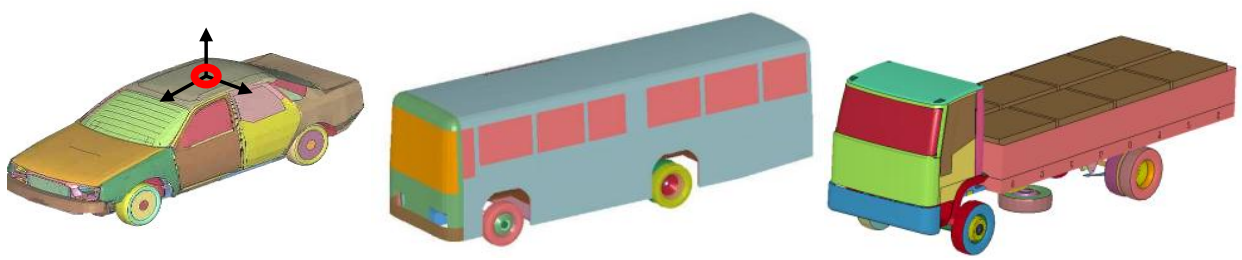

Fig.4 Finite element models of Small cars, medium bus and medium trucks

According to impact conditions of grade A barrier in "Standard for Safety Performance Evaluation of Highway Barrier" (JTG B05-01-2013),impact test conditions of small passenger cars, medium bus and medium trucks are shown in Table 4[11] [12]. 
Tab.4 Car, medium bus and medium truck collision simulation conditions

\begin{tabular}{c|c|c|c|c}
\hline Type & Total mass $(\mathrm{t})$ & Velocity $(\mathrm{km} / \mathrm{h})$ & Angle of impaction $\left({ }^{\circ}\right)$ & Energy $(\mathrm{kJ})$ \\
\hline Car & 1.5 & 100 & 20 & 1 \\
\hline medium bus & 10 & 60 & 20 & 160 \\
\hline medium truck & 10 & 60 & 20 & 160 \\
\hline
\end{tabular}

\section{Simulation Analysis}

According to "Standard for Safety Performance Evaluation of Highway Barrier", for car, medium bu and medium truck, respectively, the barrier function, guiding function, buffering function, the maximum lateral dynamic deformation of the barrier, maximum lateral dynamic displacement of the barrier, maximum lateral epitaxial dynamic displacement value of the barrier, vehicle dynamic extraverted maximum value and the maximum dynamic vehicle extraverted equivalents are analyzed through simulation analysis, the evaluation results were shown in Table 5:

\section{Full-scale impact test}

According to simulations of finite element analysis, Option I (new $4 \mathrm{~mm}$ three-wave beam) and Option II (extra column, double waveform w-beam), which were the optimum solution, were chose to pass a real vehicle impact test. The method of safety performance evaluation is in "Standard for Safety Performance Evaluation of Highway Barrier"(JTG B05-01-2013).

\section{The results of full scale impact test with real vehicle of Option I (new $4 \mathrm{~mm}$ three-wave beam)}

The impact test of real car for minibus, medium-sized car and medium truck for the new modification program $(4 \mathrm{~mm}$ w-beam)are shown in Figure 5.

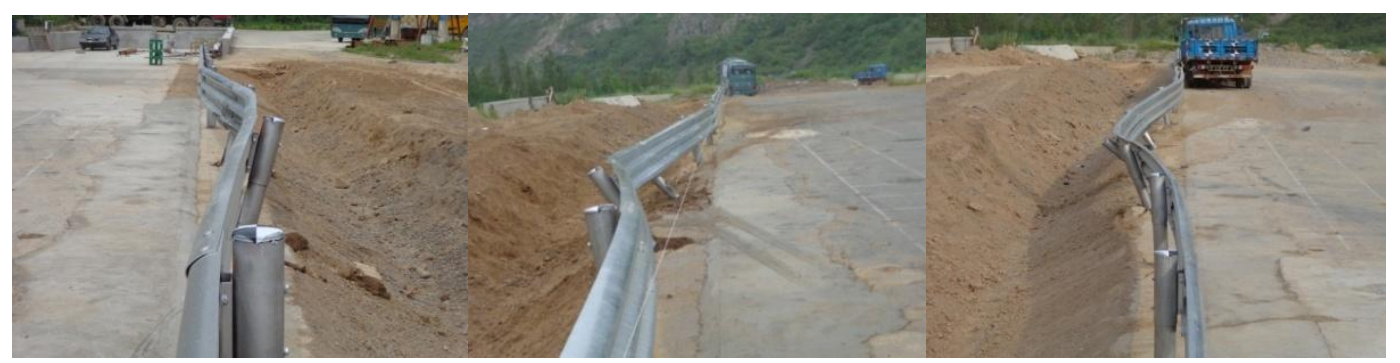

Fig. 5 Deformation of barrier collision of a car, medium bus and medium truck of option II

From the testing process, when a small car impacted, the collision between the vehicle tire and collided barrier column happened, but the collision did not affect the running attitude of the vehicle, the car could be relatively stably guided and the impact-side front tire blow out, when impact happened occupants suffered much larger acceleration, but acceleration did not exceed the requirements of specified limit values; when medium-sized bus impacted, vehicle rolling was large, the front portion of the vehicle had a tilt phenomenon, but after landing vehicle could still be driving normally, and did not leave exit box, the earth shoulder of the road was severely damaged and vehicle rolled over a collision zone column. Deformation of the column was large; When a medium truck impacted, vehicle rolled seriously, when rolling the vehicle steering wheel deflected, resulting in the truck cannot run along a straight line when the wheels landed, the vehicle ran against and rubbed the barrier until parking, deformation of barrier was large, and some part shads light tearing. According to the results, the safety performance of this design meet the Level A class protection requirements. 
Tab.5 Evaluation of renovation option simulation

\begin{tabular}{|c|c|c|c|c|c|c|c|c|c|c|c|c|c|c|}
\hline \multirow{3}{*}{\multicolumn{2}{|c|}{$\begin{array}{l}\text { Evaluation } \\
\text { items }\end{array}$}} & \multicolumn{2}{|c|}{$\begin{array}{l}\text { Containment } \\
\text { performance }\end{array}$} & \multicolumn{2}{|c|}{ Redirective performance } & \multicolumn{4}{|c|}{ Buffering performance } & \multirow{3}{*}{$\begin{array}{c}\text { Maximum } \\
\text { dynamic } \\
\text { lateral } \\
\text { deflection } \\
(\mathrm{mm})\end{array}$} & \multirow{3}{*}{$\begin{array}{l}\text { Maximum } \\
\text { dynamic } \\
\text { widening } \\
\text { distance of } \\
\text { lateral } \\
\text { deflection } \\
(\mathrm{mm})\end{array}$} & \multirow{3}{*}{$\begin{array}{l}\text { Maximum } \\
\text { dynamic } \\
\text { vehicle } \\
\text { incline-out } \\
\text { distance } \\
(\mathrm{mm})\end{array}$} & \multirow{3}{*}{$\begin{array}{l}\text { normalized } \\
\text { maximum } \\
\text { dynamic } \\
\text { vehicle } \\
\text { incline-out } \\
\text { distance } \\
(\mathrm{mm})\end{array}$} & \multirow{3}{*}{$\begin{array}{l}\text { Meets the } \\
\text { evaluation } \\
\text { criteria or } \\
\text { not }\end{array}$} \\
\hline & & \multirow{2}{*}{$\begin{array}{c}\text { Roll } \\
\text { over } \\
\text { or } \\
\text { not }\end{array}$} & \multirow{2}{*}{$\begin{array}{l}\text { Components } \\
\text { and } \\
\text { detachment } \\
\text { parts intrude } \\
\text { vehicle } \\
\text { occupant } \\
\text { cabin } \\
\end{array}$} & \multirow{2}{*}{$\begin{array}{l}\text { The } \\
\text { vehicle } \\
\text { roll } \\
\text { over or } \\
\text { not }\end{array}$} & \multirow{2}{*}{$\begin{array}{l}\text { The vehicle to } \\
\text { meet the } \\
\text { requirements } \\
\text { of exit box }\end{array}$} & \multicolumn{2}{|c|}{$\begin{array}{c}\text { Occupant } \\
\text { impact } \\
\text { velocity }(\mathrm{m} / \mathrm{s})\end{array}$} & \multicolumn{2}{|c|}{$\begin{array}{c}\text { Occupant } \\
\text { ride down } \\
\text { acceleration }(\mathrm{g})\end{array}$} & & & & & \\
\hline & & & & & & $\mathrm{x}$ & $\mathrm{Y}$ & $\mathrm{x}$ & $\mathrm{Y}$ & & & & & \\
\hline \multirow{3}{*}{ I } & Car & no & no & no & yes & 5.1 & 7.7 & 7.7 & 8.6 & 659 & 1016 & - & - & \multirow{3}{*}{ yes } \\
\hline & $\begin{array}{c}\text { medium } \\
\text { bus }\end{array}$ & no & no & no & yes & - & - & - & - & 1296 & 1576 & 1498 & 1848 & \\
\hline & $\begin{array}{c}\text { medium } \\
\text { truck }\end{array}$ & no & no & no & yes & - & - & - & - & 1012 & 1310 & 1482 & 2270 & \\
\hline \multirow{3}{*}{ II } & Car & no & no & no & yes & 3.2 & 5.9 & 6.9 & 8.2 & 585 & 1536 & - & - & \multirow{3}{*}{ yes } \\
\hline & $\begin{array}{c}\text { medium } \\
\text { bus }\end{array}$ & no & no & no & yes & - & - & - & - & 1188 & 1558 & 2268 & 2618 & \\
\hline & $\begin{array}{c}\text { medium } \\
\text { truck }\end{array}$ & no & no & no & yes & - & - & - & - & 1195 & 1635 & 2574 & 3024 & \\
\hline \multirow{3}{*}{ III } & Car & no & no & no & yes & 11 & 7.7 & 16.7 & 7.8 & 419 & 1538 & - & - & \multirow{3}{*}{ yes } \\
\hline & $\begin{array}{c}\text { medium } \\
\text { bus }\end{array}$ & no & no & no & yes & - & - & - & - & 835 & 1739 & 914 & 1359 & \\
\hline & $\begin{array}{c}\text { medium } \\
\text { truck }\end{array}$ & no & no & no & yes & - & - & - & - & 815 & 1821 & 1375 & 1820 & \\
\hline \multirow{3}{*}{$\mathrm{IV}$} & Car & no & no & no & yes & 9.7 & 9.3 & 11.1 & 8 & 422 & 1462 & - & - & \multirow{3}{*}{ no } \\
\hline & $\begin{array}{c}\text { medium } \\
\text { bus }\end{array}$ & yes & no & no & yes & - & - & - & - & - & - & - & - & \\
\hline & $\begin{array}{c}\text { medium } \\
\text { truck }\end{array}$ & no & no & no & yes & - & - & - & - & 787 & 1499 & 1516 & 1961 & \\
\hline \multirow{3}{*}{$\mathrm{V}$} & Car & no & no & no & yes & \begin{tabular}{|l|}
9.9 \\
\end{tabular} & 10 & 10.5 & 6.9 & 411 & 1504 & - & - & \multirow{3}{*}{ no } \\
\hline & $\begin{array}{c}\text { medium } \\
\text { bus }\end{array}$ & no & no & no & yes & - & - & - & - & 774 & 1047 & 765 & 1210 & \\
\hline & $\begin{array}{c}\text { medium } \\
\text { truck }\end{array}$ & no & no & no & no & - & - & - & - & 792 & 1529 & 1588 & 2032 & \\
\hline
\end{tabular}

Results of Option II (extra column, double waveform w-beam) of full-scale impact test with real vehicle

Real car impact test of modification option of adding extra column, double waveform w-beam of car, medium bus and medium truck are shown below respectively, in Figure 6.

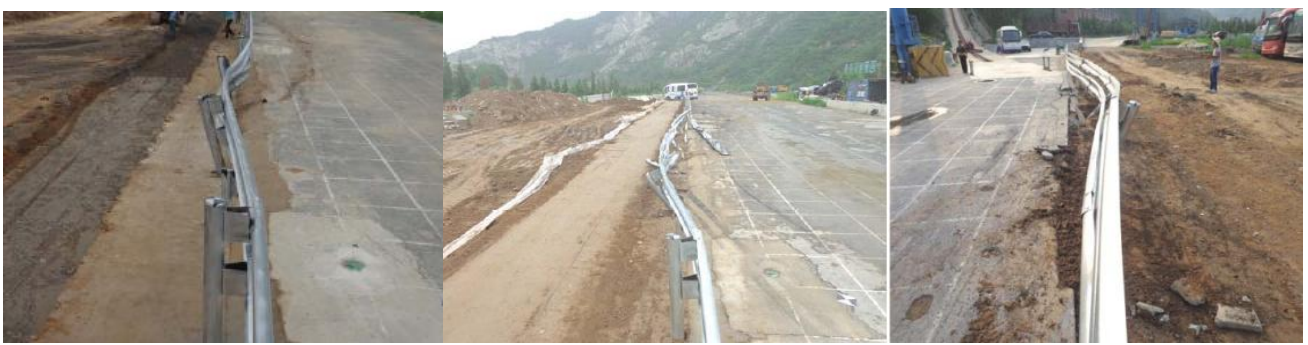

Fig. 6 Deformation of barrier impact of a car, medium bus and medium truck of option II

From the testing process, when a small passenger car impacted the collision between the vehicle tire and collided barrier column happened, most of impact happened on the lower layer plate of barrier; large deformation took place on the lower layer barrier, while the lower column had weaker stiffness (diameter $114 \mathrm{~mm}$ ).After forming "string bag" phenomenon, the vehicle was guided due to the synergistic interception effect of column and high barrier plate and collision happened between the wheel and high column (diameter 140mm), the front side tire of the vehicle fell out, the vehicle was successfully exported.

When medium-sized bus impact, upper barrier deformation occurs firstly because the vehicle height, the wheels climb on the barrier. When the tire pressed on the barrier, the barrier deformation took place and the vehicle hit the vehicle directly on the lower short column, at this time the upper barrier deformed normally and the guiding function for the vehicle is formed, but at this time the lower barrier was completely deformed on the road. When the vehicle continued to move, the lower barrier plate fractured and the lower column fall down. Vehicle was successfully exported.

When a medium truck impact, vehicle rolled more seriously, in the rolling process, the vehicle 
steering wheel deflected, leading to that vehicles cannot travel in a straight line when the wheel landing, the vehicle ran against the barrier and rub until the parking. Different from the situation of the medium-sized passenger car impacted, truck did not climb along the lower board of the barrier in the early stages. The main reason was the medium truck had different mass distribution between trucks and medium bus, and the impact force of the collision is less than the medium bus in initial period.

\section{Conclusion}

Based on the usage survey of old beam barrier, the calculation model of the old beam barrier actual protection level promotion was established, the factor of barrier protection level, of which the column section modulus, strength of steel, columns buried depth, soil base compaction, relative rotation angle of plastic deformation of the column and other factors, were analyzed;

Combined with previous research experience and theoretical calculations, the five kinds of barrier structure whose protection capacity were enhanced were suggested, and the theoretical protection level was calculated. Two final choice of barrier was chose through computer simulation analysis method and comparative analysis of performance of protection programs to conduct the full-scale impact test with real vehicle, the test results showed that the protection performance of the this two barriers program could meet the current level A requirements $(160 \mathrm{~kJ})$ of the evaluate standard, and these two could be applied to the actual construction. But in practical applications, for the protection performance of the relatively lower height of the barrier due to overlays roads, as well as column force analysis with narrow soil shoulder width, further researches are needed.

\section{Acknowledgements}

Ministry of transport construction projects of science and technology:

Research on anti-collision ability promotion transformation technology of the w-beam barrier on highway $(2013,318,223,450)$

\section{Reference}

[1] Bai-lai Liu, Zhu-long Li, Yong-gao Shi, etc. Energy Conversion Analysis of W-beam Guardrail with Side Collision. Journal of Xi'an Technological University [J]. 2008, (12) (In Chinese)

[2] Hao-lan Yang. Research on the wave beam barrier and set up technical. Highway and Transportation Research and Technology Applications [J]. 2015, (6) (In Chinese)

[3] Yong Zhong, Cheng-hu Wang. Research on new beam barrier protection performance Limit .Highway and Transportation Research and Technology Applications [J]. 2015, (6) (In Chinese)

[4] Jun Wei, Xiu-na Jin, Rong-zhen Dong, etc. Research on affect the structural parameters of the beam barrier crash performance. Journal of Wuhan University of Technology [J]. 2013, (4) (In Chinese)

[5] Tong-xi Yu, Guo-xing Lu. Energy absorbing materials and structures [M] Beijing: Chemical Industry Press, 2005. (In Chinese)

[6] Guardrail set standards · with commentary. 2004 edition. (In Japan)

[7] Wei-gang Zhang, Gao-xian Hu. Finite Element Model of a W-beam Guardrail Post Mounted in Soil. Highway and Transportation Research [J]. 2007, (7) (In Chinese) 
[8] Gao-xian Hu. A Simulation Study on the Effect of soil foundation on the Crashworthiness of the guardrail [D] Hunan: Hunan University, 2007. (In Chinese)

[9] People's Republic of China Industrial Standard .JTG D81-2006Specificationfor Design of Highway Safety facilities [S] Beijing: China Communications Press, 2006. (In Chinese)

[10] People's Republic of China recommended Industrial standards .JTG / T D81-2006 Guidelines for Design of Highway Safety Facilities [S] Beijing: China Communications Press, 2006. (In Chinese)

[11] People's Republic of China recommended standards TG / T F83-01-2004 Standard for Safety Performance Evaluation of Highway Barriers [S]. Beijing: China Communications Press, 2004. (In Chinese)

[12] People's Republic of China Industrial Standard .JTG B05-01-2013 Standard for Safety Performance Evaluation of Highway Barriers [S] Beijing: China Communications Press, 2013. (In Chinese) 